\title{
BAURAN PEMASARAN BUNGA GERBERA (Gerbera jamensonii) DI KELOMPOK TANI BOEMI NURSERY JAWA BARAT
}

\author{
Yoli Okta Lifia ${ }^{1}$ Rika Hariance ${ }^{2}$ \\ ${ }^{1}$ Mahasiswa Program Studi Agribisnis, Politeknik Pertanian Negeri Payakumbuh \\ 2 Staf Pengajar Program Studi Agribisnis Universitas Andalas Padang \\ Email: megaamelia@yahoo.com
}

\begin{abstract}
ABSTRAK
Gerbera (Gerbera jamensonii) merupakan salah satu jenis tanaman hias yang memiliki nilai ekonomis tinggi dan sangat prospektif untuk dikembangkan secara komersial terutama sebagai produk bunga potong. Kelompok tani Boemi Nursery merupakan satu penghasil bunga gerbera potong yang berada di daerah Lembang, Kabupaten Bandung Barat. Salah satu penunjang keberhasilan suatu perusahaan adalah bagaimana perusahaan itu menyalurkan dan memasarkan produkproduknya. Oleh karena itu kegiatan pemasaran merupakan hal penting bagi perusahaan. Penulisan bertujuan untuk menjelaskan kegiatan budidaya bunga gerbera yang dilakukan di Kelompok Tani Boemi Nursery dan mengetahui bauran pemasaran bunga gerbera di Kelompok Tani Boemi Nursery. Penelitian ini dilaksanakan pada 1 April 2016 sampai dengan 4 Juni 2016 bertempat di Kelompok Tani Boemi Nursery. Metode pengumpulan data yang digunakan adalah wanwancara, observasi dan dokumentasi. Kelompok Tani Boemi Nursery melakukan bauran pemasaran terhadap produknya yaitu bunga gerbera dengan berbagai warna seperti merah, kuning, orange dan pink. Bunga dijual per ikat dengan jumlah satu ikat sebanyak 10 tangkai. Harga yang ditawarkan untuk pemasaran tidak langsung sebesar Rp 6.500,00 per ikat sedangkan untuk pemasaran secara langsung sebesar Rp 7.500,00 per ikat. Promosi yang dilakukan dalam memasarkan produknya yaitu open house, promosi dari mulut ke mulut, mengikuti seminar dan media sosial. Kelompok tani Boemi Nursery harus membuat manajemen usaha tanaman hias ini lebih baik lagi dengan melakukan pencatatan untuk semua kegiatan yang dilakukan dan pembukuan keuangan dari usaha kelompok tani tersebut. Sehingga usaha yang dijalankan terencana dan terkoordinir dan dapat berjalan sesuai yang diharapkan.
\end{abstract}

Kata kunci: gerbera, teknik budidaya, bauran pemasaran.

\section{PENDAHULUAN}

Gerbera (Gerbera jamensonii) merupakan salah satu jenis tanaman hias yang memiliki nilai ekonomis tinggi dan sangat prospektif untuk dikembangkan secara komersial terutama sebagai produk bunga potong. Kultivar baru hibrid yang semakin berkembang dengan beraneka ragam bunga, mulai dari putih, kuning, orange, merah muda, merah dan scarlet menyebabkan bunga potong gerbera menjadi salah satu primadona konsumen untuk kebutuhan dekorasi.

Awalnya di Indonesia gerbera hanya ditanam sebagai tanaman sela diantara tanaman sayuran, karena permintaan konsumen di pasaran tidak terlalu banyak. Sebelum berkembangnya kultivar baru, konsumen tidak menyukai gerbera sebagai materi rangkaian karena tidak mempunyai aroma dan ujung tangkai bunganya cepat layu. Namun setelah muncul gerbera hibrid dengan diameter bunga yang besar $(10 \mathrm{~cm})$ dan dengan aneka ragam warna, maka peluang permintaan bunga potong gerbera cukup besar.

Kelompok tani Boemi Nursery merupakan perusahaan yang bergerak di bidang agribisnis pertanian yaitu budidaya dan pemasaran tanaman hortikultura. Jenis tanaman hortikultura yang dihasilkan adalah tanaman hias berupa bunga gerbera potong, bunga mawar potong dan daun-daun potong.

Salah satu penunjang keberhasilan suatu perusahaan adalah bagaimana perusahaan itu menyalurkan dan memasarkan produk-produknya. Oleh karena itu kegiatan pemasaran merupakan hal penting bagi perusahaan. Pemasaran merupakan suatu proses interaksi sosial antara individu dengan kelompoknya untuk mendapatkan apa yang dibutuhkan dan diinginkan diperoleh dengan menciptakan, menawarkan, serta melakukan pertukaran barang dan jasa kepada pihak lain (Lubis, 
2004). Dengan demikian produsen atau penjual harus menyediakan produk yang sesuai dengan keinginan konsumen. Suatu atribut produk dapat membedakan antara satu produk yang dipasarkan oleh perusahaan yang satu dengan produk yang sama yang ditawarkan oleh perusahaan lain.

Peranan pemasaran saat ini tidak hanya menyampaikan produk atau jasa sampai ke tangan konsumen tetapi juga bagaimana produk atau jasa tersebut dapat memberikan kepuasan kepada pelanggan dengan menghasilkan laba. Sasaran dari pemasaran adalah menarik pelanggan baru dengan menjanjikan nilai superior, menetapkan harga menarik, mendistribusikan produk dengan mudah, mempromosikan secara efektif serta mempertahankan pelanggan yang sudah ada dengan tetap memegang prinsip kepuasan pelanggan (Shinta, 2012).

Salah satu bentuk strategi pemasaran yang mampu mendukung dalam memasarkan produk untuk menciptakan kepuasan konsumen adalah penggunaan bauran pemasaran (marketing mix) yang meliputi product, price, place dan promotion (Rachmawati, 2011). Dengan demikian, faktor yang ada dalam bauran pemasaran (marketing mix) merupakan variabel-variabel yang diharapkan mampu menciptakan kepuasan konsumen, atau dengan kata lain variabel-variabel tersebut akan mempengaruhi kepuasan konsumen dalam membeli suatu produk. Kepuasan pelanggan akan berimbas kepada loyalitas pelanggan, sehingga usaha yang dibangun akan terus bertahan dan berkembang. Dengan tujuan Menjelaskan kegiatan budidaya bunga gerbera yang dilakukan di Kelompok Tani Boemi Nursery. Mengetahui dan memahami bauran pemasaran bunga gerbera yang dilakukan oleh Kelompok Tani Boemi Nursery.

\section{METODE PENELITIAN}

Penelitian ini dilakukan selama 2 bulan yaitu dimulai 1 April 2016 sampai 4 Juni 2016. Bertempat di Kelompok Tani Boemi Nursery, bergerak dibidang agribisnis pertanian yaitu budidaya tanaman hortikultura dan pemasaran. Kajian ini mencakup tentang teknik budidaya bunga gerbera dan bauran pemasaran yang meliputi empat aspek yaitu produk, harga, tempat dan promosi dalam pemasaran bunga gerbera potong di Kelompok Tani Boemi Nursery desa Cikahuripan Kecamatan Lembang Kabupaten Bandung Barat, Jawa Barat. Langkah-langkah yang ditempuh dan teknik yang digunakan untuk mengumpulkan data yang diperlukan sebagai berikut wawancara, observasi, dokumentasi.

\section{HASIL DAN PEMBAHASAN}

\section{Gambaran Umum Perusahaan}

Kelompok Tani Boemi Nursery sudah mulai dirintis pada tanggal 19 Januari 2005 yang berfungsi sebagai wadah informasi dan pemasaran bunga potong yang saat itu beranggotakan 5 orang petani bunga potong. Dengan pengelolaan "kumaha ceuk sorangan" yang artinya semua informasi dan teknologi budidaya tanaman dikembangkan secara individu, terbatas dan sederhana. Namun demikian tidak mengurangi semangat untuk menciptakan bunga potong yang berkualitas yang dapat diterima pasar atau konsumen.

Memasuki tahun 2009, Kelompok Tani Boemi Nursery dikukuhkan oleh instansi pertanian setempat sebagai salah satu kelompok tani bunga potong di daerah Lembang. Pengukuhan ini terjadi pada hari Sabtu tanggal 21 Maret 2009 pukul 20.00 WIB dengan beranggotakan 25 orang petani bunga potong yang bertempat didesa Cikahuripan Kecamatan Lembang Kabupaten Bandung Barat. Dengan demikian kelompok ini secara legal diakui keberadaannya oleh pemerintah setempat.

Kelompok tani ini dipimpin oleh Bapak Rachmad Hidayat Muchlis, S.Pd yang dahulu berprofesi sebagai karyawan perhotelan di daerah tersebut. Selama bekerja sebagai karyawan perhotelan beliau sering kali bertanggung jawab dalam dekorasi dan penggadaan bunga segar untuk keperluan hotel. Melihat permintaan bunga segar yang tinggi, sekitar akhir tahun 2004 beliau memutuskan untuk berhenti bekerja. Dengan berbekal pengalaman yang ada, beliau memberanikan diri untuk mulai merintis usaha budidaya bunga potong. Pada tahun 2013 produk bunga Kelompok Tani Boemi Nursery melalui Lembaga Pendidikan Merangkai Bunga Herasri dapat diperkenalkan dan diterima oleh Istana Negara. Tidak hanya itu, kelompok tani ini juga sering di panggil sebagai narasumber pada berbagai acara tentang budidaya tanaman hias. Selain itu, Kelompok Tani Boemi Nursery juga sering menjadi pemenang pada berbagai acara pameran, perlombaan merangkai bunga dan lainnya. 


\section{Struktur Organisasi Perusahaan}

Struktur orgasnisasi di Kelompok Tani Boemi Nursery hanya terdiri dari bentuk kepengurusan secara umum dengan bidang koordinasinya masing-masing tanpa adanya keanggotaan dari bidang koordinasi tersebut. Setiap bidang koordinasi langsung bertanggung jawab terhadap ketua dan begitu sebaliknya, ketua langsung bertanggungjawab terhadap setiap bidang koordinasi yang dinaunginya. Berikut merupakan susunan kepengurusan dan kelembagaan dari Kelompok Tani Boemi Nursey yang dapat dilihat pada Gambar 1

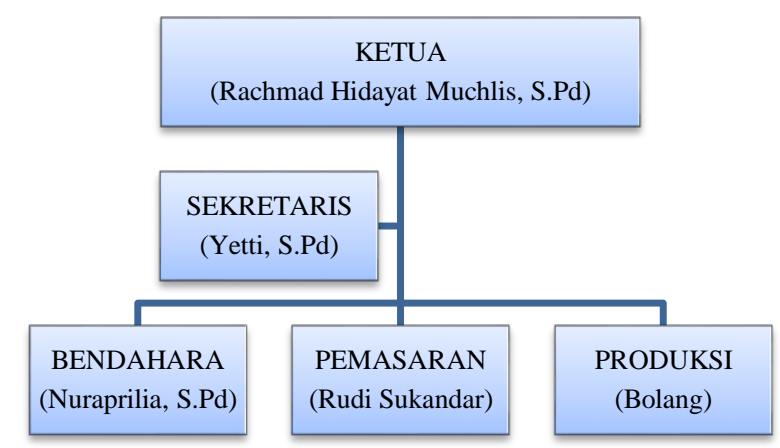

Gambar 1. Stuktur Organisasi Kelompok Tani Boemi Nursery

\section{Sumber Daya Manusia}

Sumber daya manusia yang ada di Kelompok Tani Boemi Nursery berjumlah 4 orang tenaga kerja tetap, dengan pembagian 1 orang sebagai tenaga kerja pengolahan lahan dan 3 orang sebagai tenaga bagian budidaya. Pada kegiatan pertanian yaitu kegiatan pertanian florikultura mencakup budidaya mawar dan garbera/hebras. Upah yang diberikan kepada tenaga kerja tetap wanita sebesar Rp 25.000,- sedangkan untuk upah tenaga kerja tetap pria sebesar Rp 50.000,-.

\section{Kondisi Keuangan secara Umum}

Kondisi keuangan di Kelompok Tani Boemi Nursery kurang baik dikarenakan untuk pencatatan pendapatan dan pengeluaran tidak dilakukan secara terperinci dan tidak ada bagian khusus yang mencatat keuangan tersebut. Sumber modal perusahaan berasal dari lembaga keuangan yaitu bank dan koperasi. Pendapatan yang diperoleh Kelompok Tani Boemi Nursery per bulannya sebesar Rp 25.000.000,- dengan laba bersih yang diperoleh oleh selama satu bulan adalah Rp 15.000.000,- sehingga dapat dikalkulasikan penghasilan perusahaan selama satu tahun $\pm \mathrm{Rp}$ 300.000.000,- dengan laba bersih sebesar Rp 180.000.000,-.

Asset yang dimiliki perusahaan lahan, angkutan, peralatan dan bangunan. Lahan terdiri dari lahan mawar seluas $1.500 \mathrm{~m}^{2}$ dan lahan garbera seluas $1.500 \mathrm{~m}^{2}$. Angkutan terdiri dari 1 kendaraan roda 4 yaitu mobil box dan 1 kendaraan roda 2 yaitu sepeda motor. Peralatan terdiri dari peralatan yang digunakan untuk kegiatan pertanian. Peralatan tersebut yaitu 2 buah cangkul, 3 buah kored, 5 buah gunting stek, 2 buah gembor dan 5 buah pisau okulasi. Bangunan yang dimiliki 1 buah yaitu sebagai kantor sekaligus tempat penanganan pasca panen.

\section{Deskripisi Kegiatan Bisnis Perusahaan}

Kegiatan bisnis yang dilakukan di Kelompok Tani Boemi Nursery yaitu meliputi kegiatan produksi, produk, pelanggan, pemasok bahan baku dan kegiatan pemasaran.

1. Teknik Budidaya

Menurut Direktorat Budidaya dan Pasca panen Florikultura (2014), kegiatan budidaya tanaman hias gerbera meliputi tahapan sebagai berikut :

1) Penyiapan lahan

2) Penyiapan pelindung tanaman

3) Penyiapan benih

4) Penanaman

5) Penyiraman

6) Penyulaman

7) Penyiangan dan perompesan

8) Pemupukan 
9) Pengendalian OPT

10) Panen

\section{Bauran Pemasaran}

Bauran pemasaran (marketing mix) merupakan bagian dari aktivitas pemasaran yang mempunyai peranan yang cukup penting dalam mempengaruhi konsumen untuk membeli produk atau jasa yang ditawarkan. Dalam marketing mix tanaman hias mencakup beberapa hal yang perlu dilakukan yaitu diantaranya memasarkan produk (Product), harga (Price), tempat (Place) dan promosi (Promotion). Kelompok Tani Boemi Nursery merupakan kelompok tani yang bergerak dalam budidaya tanaman hias dan sekaligus melakukan pemasaran terhadap tanaman hias yang dibudidayakannya.

\section{a. Produk (Product)}

Menurut Rachmawati (2011), produk adalah keseluruhan konsep objek atau proses yang memberikan sejumlah nilai manfaat kepada konsumen. Salah satu kunci membangun strategi pemasaran adalah menawarkan produk yang sesuai dengan kebutuhan pelanggan. Sebagus apapun produk yang ditawarkan jika tidak sesuai dengan kebutuhan pelanggan akan ditolak.

Produk yang ditawarkan di Kelompok Tani Boemi Nursery yaitu bunga gerbera. Bunga gerbera ini memiliki warna yang bervariasi merah, kuning, oren, pink dan putih. Varietas yang ditanam adalah Gerbera popop, estelle, penny, monaco, roulette, horizon dan king. Bunga gerbera yang dipanen memiliki kelopak bunga yang bagus dan panjang tangkai rata-rata $40-65 \mathrm{~cm}$. Bunga gerbera dijual per ikat kecil dengan jumlah satu ikat sebanyak 10 tangkai. Kemudian bunga gerbera dalam ikatan kecil di ikat lagi menjadi ikatan besar dengan jumlah satu ikat besar sebanyak 5 ikat kecil. Sehingga konsumen dapat membeli bunga gerbera potong dengan satu warna atau beraneka warna dalam satu ikat besar, dapat dilihat pada Gambar 2 di bawah ini

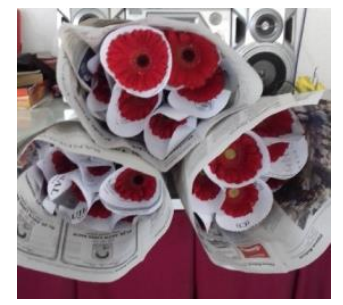

Gambar 2. Bunga gerbera siap dikemas

Menurut Shinta A (2012), kemasan yang baik harus memenuhi persyaratan sebagai berikut: 1) Sebagai daya tarik terhadap konsumen; 2) Mempunyai ukuran, bentuk dan bobot yang sesuai dengan norma atau standar yang ada, mudah dibuang dan mudah dibentuk atau dicetak; 3) Memudahkan dalam penanganan, pengangkutan, distribusi, penyimpanan dan penyusunan/penumpukan; 4) Dapat melindungi isinya dari berbagai risiko dari luar, misalnya perlindungan dari udara panas/dingin, sinar matahari, bau asing, benturan/tekanan mekanis dan kontaminasi mikroorganisme. Bunga gerbera dikemas dengan menggunakan kertas koran atau kertas yang lainnya. Kertas koran ini dipilih karena memudahkan dalam penanganan pasca panen, pengangkutan, penyusunan dan juga dapat melindungi dari sinar matahari langsung dan menjaga kelembapan dari bunga tersebut. Sebelum dikemas kelopak bunga gerbera diberi kertas yang telah dibuat menjadi corong terlebih dahulu yang bertujuan agar kelopak bunga tidak rontok.

\section{b. Harga (Price)}

Harga adalah sejumlah uang yang harus dibayarkan pelanggan untuk memperoleh produk. Kelompok Tani Boemi Nursery melakukan pemasaran bunga gerbera secara langsung dan tidak langsung, sehingga harga yang ditawarkan pada bunga gerbera juga berbeda. Harga yang ditawarkan untuk pemasaran tidak langsung sebesar Rp 6.500,00 per ikat kecil sedangkan untuk pemasaran secara langsung sebesar Rp 7.500,00 per ikat kecil.

Periode pembayaran adalah cicilan sesuai kesepakatan antara penjual dan pembeli biasanya berhubungan dengan kredit. Menurut Mursid (2010), periode pembayaran dibagi kedalam 3 bagian, yaitu: jangka pendek, jangka menengah dan jangka panjang. Kelompok Tani Boemi Nursery ini 
juga melakukan bentuk pembayaran secara kredit bagi konsumen yang sering membeli bunga (langganan) dari kelompok tani ini. Biasanya periode pembayaran yang dilakukan dalam jangka waktu pendek dengan waktu yang diberikan antara satu minggu hingga satu bulan.

\section{c. Tempat (Place)}

Kelompok tani ini menghasilkan bunga-bunga yang berkualitas dengan harga yang terjangkau sehingga mampu bersaing di pasarnya. Kegiatan pemasaran merupakan hal penting bagi perusahaan salah satunya mencakup kegiatan saluran distribusi. Tujuan kegiatan saluran distribusi yang di jalankan oleh perusahaan tidak lain adalah memberikan kemudahan bagi konsumen sehingga dapat dengan mudah memenuhi kebutuhannya (Santosa, 2010).

Menurut Mursid (2010), fungsi saluran distribusi antara lain: 1) Sebagai alat memperlancar keuangan perusahaan, uang tunai cepat masuk bila menggunakan saluran distribusi dibanding dengan perusahaan menjual sendiri produknya. Agen/whole seller bisa langsung mengambil barang dalam jumlah yang besar. Kalau perusahaan yang menjual, harus menunggu konsumen datang dan jumlah yang dibeli relatif sedikit; 2) Sebagai alat komunikasi, perusahaan banyak memperoleh masukan/informasi dari agen mengenai reaksi/respon produk yang dikeluhkan konsumen; 3) Sebagai alat bantu penjualan/promosi. Untuk pendistribusiannya, saluran distribusi yang diterapkan di kelompok tani Boemi Nursery ini adalah sebagai berikut:

\section{Distribusi langsung}

Saluran distribusi langsung (saluran tingkat nol) yaitu dalam proses penyaluran produk dari produsen ke konsumen tidak terdapat perantara, produsen langsung berhubungan dengan konsumen, untuk melancarkan penyaluran biasanya membentuk nilai unit penjualan. Kelompok tani Boemi Nursery melakukan penjualan bunga gerbera secara langsung kepada pedagang bunga atau florist di daerah lembang tersebut, salah satu pedagang yang menjadi langganan tetap yaitu Lili, beliau hampir tiap hari memesan bunga gerbera potong disini. Dalam seminggu Lili memesan bunga gerbera rata-rata sebanyak 200 ikat.

\section{Distribusi tidak langsung}

Saluran distribusi tidak langsung yang digunakan adalah saluran tingkat dua yaitu terdapat lebih dari satu perantara yang merupakan lembaga pemasaran yang menghubungkan produsen ke konsumen. Selain melakukan pendistribusian bunga gerbera potong secara langsung, kelompok tani Boemi Nursery juga melakukan pemasaran bunga gerbera potong secara tidak langsung yaitu dengan menggunakan saluran distribusi tingkat dua. Kelompok tani Boemi Nursery menjual bunga gerbera potong melalui agen kemudian agen menyalurkan bunganya ke pedagang pengecer atau ke tempat dekorasi setelah itu barulah bunga tersebut sampai ke tangan konsumen. Daerah pemasarannya yaitu di sekitar Kota Bandung dan Jakarta. Untuk disekitar Kota Bandung bunga gerbera di pasarkan di Westu Kencana, Pandu, Tega Lega dan jamika, sedangkan untuk di Kota Jakarta pemasarannya di Rawa Belong dan Blok M.

\section{d. Promosi (Promotion)}

Promosi merupakan faktor yang sangat penting dalam pemasaran. Promosi adalah usaha sadar untuk melakukan sosialisasi, penerangan dan pemberitahuan kepada masyarakat tentang berbagai informasi yang biasanya mengenai berbagai produk yang ditawarkan. Aktivitas promosi melibatkan berbagai bentuk dan variasi yang sangat beragam. Promosi bertujuan agar dapat meningkatkan penjualan, mengumumkan lokasi agen dan mengumumkan perubahan/penyempurnaan produk. Menurut Mursid (2010), promosi dapat dilakukan dengan berbagai cara yaitu: periklanan (advertising), personal selling, publisitas dan sales promotion. Bentuk promosi yang dilakukan Kelompok Tani Boemi Nursery adalah:

- Open house. Kegiatan open house yang dilakukan merupakan perkumpulan beberapa kelompok tani pada salah satu rumah dari kelompok tani tersebut secara bergilir yang diadakan satu kali dalam sebulan.

- Promosi dari mulut ke mulut.

- Mengikuti pameran tanaman hias.

- Media sosial, seperti : Blackberry Messeger, facebook dan Instagram. 


\section{KESIMPULAN}

Kelompok Tani Boemi Nursery merupakan perusahaan yang bergerak di bidang pertanian khususnya hortikultura yang melakukan budidaya dan pemasaran bunga potong di Desa Cikahuripan Kecamatan Lembang Kabupaten Bandung Barat, Jawa Barat. Kegiatan budidaya bunga gerbera yang dilakukan yaitu mulai dari Penyiapan lahan sampai ke penanganan pasca panen.

Salah satu kunci membangun strategi pemasaran adalah menawarkan produk yang sesuai dengan kebutuhan pelanggan. Sebagus apapun produk yang ditawarkan jika tidak sesuai dengan kebutuhan pelanggan akan ditolak. Kelompok Tani Boemi Nursery melakukan bauran pemasaran terhadap produknya yaitu bunga gerbera dengan berbagai warna seperti merah, kuning, oren dan pink. Bunga dijual per ikat dengan jumlah satu ikat sebanyak 10 tangkai. Harga yang ditawarkan sebesar Rp 6.500,00 per ikat kecil untuk pemasaran tidak langsung dan $\mathrm{Rp} 7.500,00$ per ikat kecil untuk pemasaran secara langsung. Promosi yang dilakukan dalam memasarkan produknya yaitu open house, promosi dari mulut ke mulut, rajin mengikuti seminar dan media sosial.

\section{DAFTAR PUSTAKA}

Dharmesta dan Irawan. 2005. Manajemen Pemasaran Modern Edisi Kedua. Liberty, Yogyakarta.

Direktorat Budidaya dan Pascapanen Florikultura. 2014. Standar Operasional Prosedur Budidaya Gerbera. Kementrian Pertanian, Jakarta.

Kotler, P dan Armstrong, G. 2008. Manajemen Pemasaran Edisi 13. Erlangga, Jakarta.

Kotler, P dan Keller. 2003. Manajemen Pemasaran Edisi 11. PT Indeks, Jakarta.

Kotler, P. 2005. Manajemen Pemasaran. PT. Prehallindo, Jakarta.

Lubis, A N. 2004. Peranan Saluran Distribusi Dalam Pemasaran Produk Dan Jasa. http://library.usu.ac.id. Diakses pada tanggal 20 Juni 2016.

Mursid, M. 2010. Manajemen Pemasaran. Bumi aksara, Jakarta.

Prihatman, K. 2000. Gerbera. http://www.ristek.go.id. Diakses pada tanggal 25 April 2016.

Rachmawati, R. 2011. Peranan Bauran Pemasaran (Marketing Mix) Terhadap Peningkatan Penjualan. http://journal.unnes.ac.id. Diakses pada tanggal 18 Juli 2016.

Santosa, S I. 2010. Saluran Distribusi Pada CV. Mitra Tirta. https://core.ac.uk. Diakses pada tanggal 27 Juni 2016.

Shinta, A. 2012. Manajemen Pemasaran. http://shinta.lecture.ub.ac.id. Diakses pada tanggal 19 Juli 2016.

Sofjan, A. 2007. Manajemen Pemasaran. PT.Rajagrafindo persada, Jakarta.

Tjiptono, F. 2008. Strategi Pemasaran. PT. Andi Offset, Yogyakarta.

Yusup, A, et al. 1999. Seri Praktek Ciputri Hijau Tuntunan Membangun Agribisnis. PT. Gramedia, Jakarta. 